\begin{tabular}{|c|}
\hline 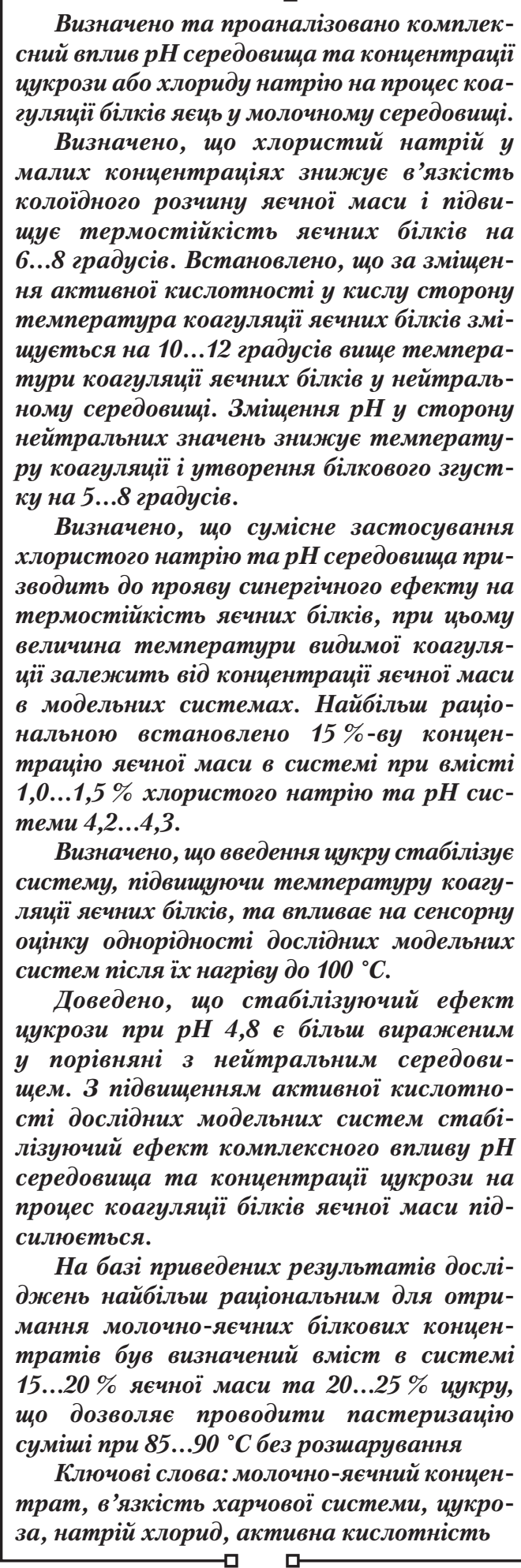 \\
\hline
\end{tabular}

Визначено та проаналізовано комплексний вплив рН середовища та концентраціи 样 малих кониентрачіях знижуе в'язкість колоїдного розчину яєчної маси $i$ підвишує термостійкість яєиних білків на ня активної кислотності у кислу сторону температура коагулячії яєчних білків зміному середовиші. Змімення рН у сторону нейтральних значень знижує температуру коагулячії і утворення білкового згустВизначено, що сумісне застосування хлористого натрію та рН середовища привеличина температури видимої коагуляції залежить від концентрації яєчної маси в модельних системах. Найбільи рачіотрацію яєчної маси в системі при вмісті 1,0...1,5\% хлористого натрію та рН сис-

систему, підвишуючи температуру коагулячії яєчних білків, та впливає на сенсорну оцінку однорідності дослідних модельних иукрози пр у порівняні з нейтральним середовисті дослідних модельних систем стабілізуючий ефект комплексного впливу рН середовища та кониентрації иукрози на процес коагуляиї̈ білків яєчної маси підНа базі приведених результатів досліджень найбільш раціональним для отритратів був визначений вміст в системі $15 . .20 \%$ яєчної маси та $20 . .25 \%$ иукру, що дозволяе проводити пастеризачію трат, в'язкість харчової системи, иукро-

Received date 02.03.2020 Accepted date 11.05.2020 Published date 30.06.2020
UDC 664.38

DOI: $10.15587 / 1729-4061.2020 .203102$

\section{SURVEY OF COMPLEX INFLUENCE OF PHYSICO-CHEMICAL AND TECHNOLOGICAL PARAMETERS ON THE PROCESS OF MILK-EGG CO-PRECIPITATE OBTAINING}

G. Deiny chenko

Doctor of Technical Sciences, Professor, Head of Department*

E-mail: deinychenkogv@ukr.net

I. Zolotukhina

$\mathrm{PhD}$, Associate Professor*

V. S k r y n n i k

Postgraduate Student**

N. F e d a k

PhD, Associate Professor**

S. T k a c h y k

Doctor of Pedagogical Sciences, Professor, Dean Pavlo Tychyna Uman State Pedagogical University

Sadova str., 2, Uman, Ukraine, 20300

T. Kravche n ko

$\mathrm{PhD}$, Associate Professor

Department of Vocational Education and

Technologies According to the Profiles

Pavlo Tychyna Uman State Pedagogical University

Sadova str., 2, Uman, Ukraine, 20300

K. K r a v c he n k o

Department of Vocational Education and

Technologies According to the Profiles

Pavlo Tychyna Uman State Pedagogical University

Sadova str., 2, Uman, Ukraine, 20300

L. De in y c he n k o

$\mathrm{PhD}$, Senior Lecturer***

O. Pavliuchenko $\mathrm{PhD}$, Associate Professor***

Y. F u r m a nova

$\mathrm{PhD}$, Associate Professor***

*Department of Processes and Equipment for Food and Hospitality-Restaurant Industry named after M. Belyaev Kharkiv State University of Food Technology and Trade Klochkivska str., 333, Kharkiv, Ukraine, 61051

**Department of Hotel, Restaurant Business and Tourism

Kharkiv State University of Food Technology and Trade Klochkivska str., 333, Kharkiv, Ukraine, 61051 ***Department of Technology of Restaurant and Ayurvedic Products National University of Food Technologies Volodymyrska str., 68, Kyiv, Ukraine, 01601

Copyright (C) 2019, G. Deinychenko, I. Zolotukhina, V. Skrynnik, N. Fedak, S. Tkachyk, T. Kravchenko, K. Kravchenko, L. Deinychenko, O. Pavliuchenko, Y. Furmanova This is an open access article under the CC BY license (http://creativecommons.org/licenses/by/4.0)

\section{Introduction}

At present, there are widely known mechanisms that predetermine the natural resistance of the child's body against infections. In particular, lysozyme (muramidase), which is characterized by the high activity against gram-positive flora, plays an undoubted protective role [1]

The introduction of lysozyme into dairy products significantly increases their biological value. Most often, specially selected lysozyme enzyme preparations, lysozyme supple- 
ments with bifidobacteria, etc., are used to enrich new baby food dairy products [2]. It is more acceptable to combine raw milk with the natural sources of lysozyme, first of all, a chicken egg. That is why it may be advisable to try to obtain a high-protein milk-egg concentrate, with a prospect of its further use in baby food technology.

It is possible to obtain milk-egg protein concentrate with high organoleptic, physicochemical, and microbiological properties by the separate pasteurization of eggs and raw milk and joint comprehensive deposition of their proteins, using sour whey as a coagulant. When co-deposited, egg proteins will act as additional centers for the coagulation of raw milk proteins, due to their significant molecular weight and a sufficient number of hydrophobic groups [3]. In addition, during heat treatment, egg proteins are denatured, turning into a gel, capable of retaining not only all the moisture of the eggs but also partially the moisture of other formulation components.

An important feature of egg proteins-is their heterogeneity, which predetermines a fairly wide range of protein coagulation temperatures [4]. The temperature of egg protein coagulation $\left(50 \ldots 95^{\circ} \mathrm{C}\right)$ differs significantly from the temperature of the latent coagulation of milk proteins, which has both positive and negative aspects. One can consider, as a positive factor, that the lower temperature of egg protein coagulation ensures the presence of ready-made coagulation centers for additional deposition of casein and whey proteins at the time of their destabilization. On the other hand, the emergence of large particles of the coagulated egg proteins long before the denaturation of globular molecules of whey proteins can yield a coagulant of inhomogeneous structure, which will reduce its qualitative characteristics.

To obtain a coagulant with high organoleptic characteristics, it is necessary, if possible, to bring the temperature of the coagulation of egg and milk proteins closer. However, since a temperature of $92 \pm 2{ }^{\circ} \mathrm{C}$ is required for the minimum heat resistance of whey proteins [5], the above temperatures can be brought closer only by increasing the coagulation temperature of egg proteins.

It is known that the introduction of some substances into the egg mass prevents the coagulation of proteins. Kitchen salt (sodium chloride) in low concentrations and sugar are used as such stabilizers. The amount of these ingredients varies depending on the technological purpose of the mixtures. Thus, sugar is added to the egg mass in an amount of 5 to $50 \%$, kitchen salt - up to $1.5 \%$. Sometimes it is practiced to add these substances in a combination. Given that obtaining a milk-egg coprecipitate could expand the range of baby food, studying the effect of sodium chloride, sucrose, and their compositions with whey on the coagulation of egg mass is a relevant scientific task.

\section{Literature review and problem statement}

The effect of sodium dodecyl sulfate on the egg proteins ovalbumin, conalbumin, and lysozyme was determined in [6]. The experiment was performed by heating protein systems from $25^{\circ} \mathrm{C}$ to $90{ }^{\circ} \mathrm{C}$ at a rate of $1.25^{\circ} \mathrm{C} / \mathrm{min}$. The performance during the deposition process involving heating was similar for all three proteins. It was determined that increasing the concentration of sodium dodecyl sulfate in the system shifted the deposition curves towards lower temperatures and the course of the deposition process became less abrupt.

The effect of heat on some physical and chemical properties of egg proteins was determined in [7] by using different temperature and time parameters. The obtained results indicated the evolution of sigmoid with a negative slope of transmission and the irreversible loss of solubility by the studied compositions. The coagulation and deposition of the examined proteins were observed at parameters of $74^{\circ} \mathrm{C} / 20 \mathrm{~min}$.

The effect of pulsed electric fields (PEF) and heat treatment on the aggregation of the egg protein ovomucin (OvEP) at different $\mathrm{pH}$ values was determined [8]. It was determined that heating to $60{ }^{\circ} \mathrm{C}$ for $10 \mathrm{~min}$ caused a pronounced aggregation of OvEP at $\mathrm{pH} 5,7$, and 9. At a constant electric field strength $(E=1.4 \ldots 1.8 \mathrm{kV} / \mathrm{cm})$, PEF treatment at high specific energy input caused some protein aggregation at $\mathrm{pH} 5$ and 7 , but not at $\mathrm{pH} 4$ and 9 . A comprehensive influence of $\mathrm{pH}$, the temperature, and pulsed electric fields on the digestibility of egg protein in vitro by the creation of protein drinks was also investigated [9]. It was determined that in order to obtain products with high digestibility it is advisable to apply the following parameters: $\mathrm{pH}$ 4, electric field strength $690 \mathrm{~kJ} / \mathrm{kg}$, temperature $80^{\circ} \mathrm{C}$.

The effect of different concentrations of $\mathrm{NaCl}$ and $\mathrm{pH}$ values on the intermolecular interactions and properties of the dispersed gel-type systems, formed on the basis of chicken egg proteins, was analyzed in [10]. The results showed that the intermolecular forces involved in the egg gel formation can be regulated by changing the $\mathrm{pH}$ and $\mathrm{NaCl}$ concentration in food systems.

In work [11], the effect of different $\mathrm{pH}$ values and salt concentration on the solubility and density of egg protein at room temperature $\left(25^{\circ} \mathrm{C}\right)$ was investigated. The experiment was performed for three types of salt $-\mathrm{NaCl}, \mathrm{Na}_{2} \mathrm{SO}_{4}$, and $\left(\mathrm{NH}_{4}\right)_{2} \mathrm{SO}_{4}$. The results showed an increase in the solubility of egg proteins with an increase in $\mathrm{pH}$ for all these salts. When the $\mathrm{pH}$ shifted to the acidic side (3.0), an increase in solubility and an increase in the concentration of salt solution due to the salinity effect were observed. The density increased with an increased salt concentration.

The effect of sodium chloride, sodium sulfate, ammonium sulfate salts, and nonionic surfactants (glycerin) on the thermal properties of egg proteins was studied in [12]. It was determined that the addition of glycerin had the greatest effect on reducing turbidity and increasing the time of thermal coagulation and solubility of the egg protein while sodium chloride had the least positive effect on the physical and chemical properties of the egg protein during heat treatment.

No fundamental studies aimed at determining the comprehensive influence of sodium chloride, sucrose, and $\mathrm{pH}$, on the coagulation process of egg proteins in a milk medium were found. Therefore, this issue remains unresolved.

\section{The aim and objectives of the study}

The study aims to determine the comprehensive influence of the physical, chemical, and technological parameters on the process of the coagulation of egg proteins in a milk environment. This will make it possible to obtain a milk-egg coprecipitate containing natural ingredients, which, in turn, will expand the range of protein-containing products made at enterprises specializing in baby food.

To achieve this aim, the following tasks were set:

- to study the comprehensive influence of sodium chloride and $\mathrm{pH}$ on the process of the thermal-acid coagulation of egg proteins in a milk medium; 
- to investigate the comprehensive influence of the medium $\mathrm{pH}$ and sucrose concentration on the process of the thermal-acid coagulation of egg proteins.

\section{Materials and methods to study the comprehensive influence of sodium chloride, sucrose, and $\mathrm{pH}$ on the coagulation process of egg proteins}

The study of the comprehensive influence of active acidity and different concentrations of sucrose or sodium chloride on the process of the coagulation of egg proteins involved the colloidal solutions of the egg mass. To prepare them, the egg mass was diluted with distilled water to the predefined concentration, followed by the introduction of sugar or salt and by stirring the mixture until completely dissolved.

To study the effect of medium $\mathrm{pH}$ on the temperature of the visible coagulation of egg proteins, the model systems involved whey, whose $\mathrm{pH}$ was brought to the required value of $0.1 \mathrm{n}$ by a solution of $\mathrm{HCl}$ and $\mathrm{NaOH}$.

Active acidity was determined using the potentiometric $\mathrm{pH}$ meter $\mathrm{pH}-340$, as well as the portable $\mathrm{pH}$ meter "Ultra-X" with a single combined electrode, which makes it possible to measure $\mathrm{pH}$ not only in biological solutions or extracts but also in food multicomponent systems [13].

The viscosity of colloidal solutions was determined by a rotational method using the rotary automatic viscometer "Rheometer DV3T Brookfield" [14].

Calculations, the evaluation of experimental data reliability, as well as plotting, were performed using methods of mathematical statistics employing the Microsoft Excel software.

\section{Results of studying the comprehensive influence of sodium chloride and $\mathrm{pH}$ on the process of the thermal- acid coagulation of egg proteins in a milk environment}

We studied the effect of sodium chloride concentration on the process of the coagulation of egg proteins by heating the model compositions, followed by the registration of the coagulation temperature based on the system viscosity. It was taken into consideration that the latent coagulation of proteins leads to an increase in the viscosity of the food system $(\eta)$ and, after protein denaturation, the formation of a protein clot and its separation from the system, the viscosity decreases sharply.

Research results are shown in Fig. 1.

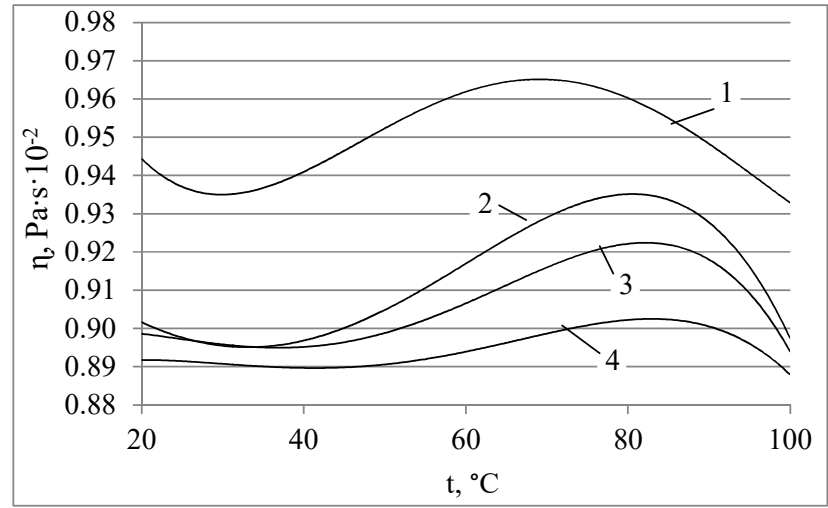

Fig. 1. Viscosity change during the heating of a colloidal solution of the egg mass of $15 \%$ concentration at $\mathrm{NaCl}$ content: $1-0 \%, 2-0.5 \%, 3-1 \%, 4-1.5 \%$
The curves are approximated and expressed by functions $(y)$ indicating the degree of the approximation reliability $\left(R^{2}\right)$ :

$y(1)=1 \mathrm{E}-08 x^{4}-3 \mathrm{E}-06 x^{3}+0,0003 x^{2}-0,0108 x+1,0626$ $R^{2}=0,8384$

$y(2)=-7 \mathrm{E}-09 x^{4}+8 \mathrm{E}-07 x^{3}+2 \mathrm{E}-08 x^{2}-0,0018 x+0,9312$, $R^{2}=0,9264$

$y(3)=-1 \mathrm{E}-08 x^{4}+2 \mathrm{E}-06 x^{3}-9 \mathrm{E}-05 x^{2}+0,0016 x+0,8902$, $R^{2}=0,961$

$y(4)=-6 \mathrm{E}-09 x^{4}+1 \mathrm{E}-06 x^{3}-8 \mathrm{E}-05 x^{2}+0,0018 x+0,8781$, $R^{2}=0,9666$.

The next step was to study the effect of medium $\mathrm{pH}$ on the temperature of the visible coagulation of egg proteins in the model systems consisting of curd whey and egg mass.

Curd whey, which is obtained in the dairy industry of Ukraine, has an active acidity in the $\mathrm{pH}$ range of $4.4 \ldots 4.8$, depending on the method of production of the main product - cottage cheese. Besides, as a result of redundancy, its active acidity may decrease to $\mathrm{pH}$ 4.2. Therefore, one of the important tasks was to establish the degree of the effect of the active acidity of curd whey in the $\mathrm{pH}$ range of $4.2 \ldots 4.8$ on the process of the thermal coagulation of egg proteins. The research results are shown in Fig. 2.
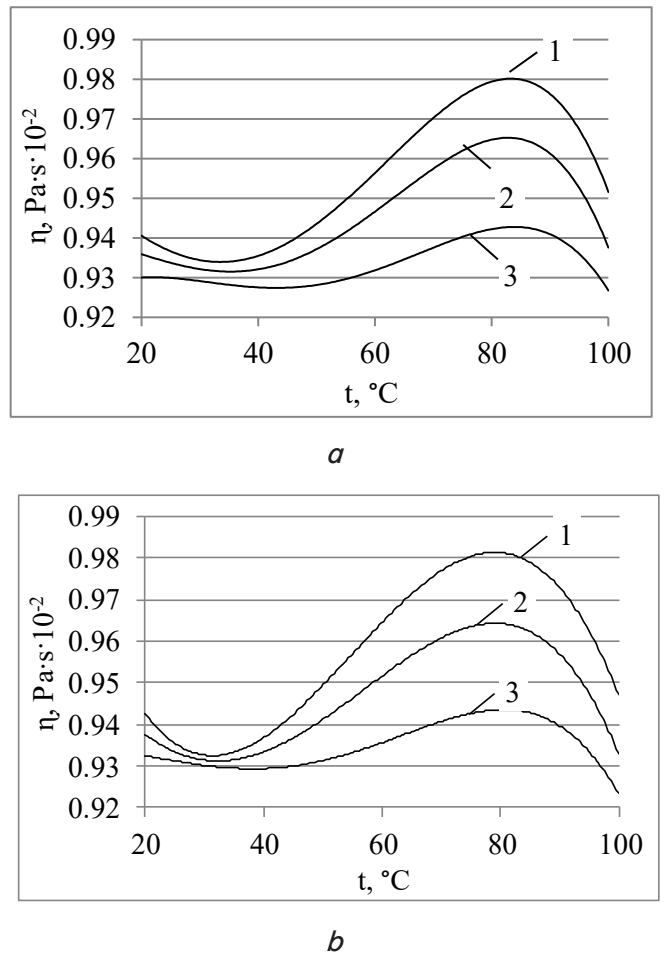

Fig. 2. Viscosity change at the heating of the colloidal solution of egg mass in the concentration of $10 \%(3)$, $15 \%$ (2), $20 \%$ (1) at pH: $a-4.2 ; b-4.6$

The curves are approximated and expressed by functions $(y)$ indicating the degree of the approximation reliability $\left(R^{2}\right)$ :

a) $y(1)=-8 \mathrm{E}-09 x^{4+} 1 \mathrm{E}-06 x^{3}-1 \mathrm{E}-05 x^{2}-0,0014 x+0,9663$, $R^{2}=0,9459$; 
$y(2)=-9 \mathrm{E}-09 x^{4}+2 \mathrm{E}-06 x^{3}-7 \mathrm{E}-05 x^{2}+0,0007 x+0,9379$, $R^{2}=0,9608$;

$y(3)=-8 \mathrm{E}-09 x^{4}+2 \mathrm{E}-06 x^{3}-0,0001 x^{2}+0,0026 x+0,9086$, $R^{2}=0,9906$

b) $y(1)=1 \mathrm{E}-09 x^{4}-1 \mathrm{E}-06 x^{3}+0,0002 x^{2}-0,0074 x+1,0314$, $R^{2}=0,8889$;

$y(2)=-3 \mathrm{E}-09 x^{4}-3 \mathrm{E}-08 x^{3}+6 \mathrm{E}-05 x^{2}-0,0034 x+0,9817$, $R^{2}=0,8866$;

$y(3)=-6 \mathrm{E}-09 x^{4}+1 \mathrm{E}-06 x^{3}-5 \mathrm{E}-05 x^{2}+0,0008 x+0,9301$, $R^{2}=0,9422$.

Next, we investigated the comprehensive influence exerted on the heat resistance of egg proteins by the medium $\mathrm{pH}$ and sodium chloride concentration in the model systems with different egg mass content. The research results are shown in Fig. 3.

The isothermal viscosity change of the system at different sodium chloride (C) concentrations is shown in Fig. 4.

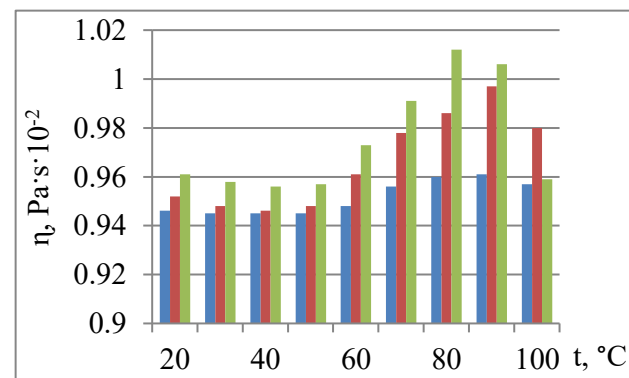

Egg mass content: $\quad \square 10 \%=15 \% \square 20 \%$

$a$

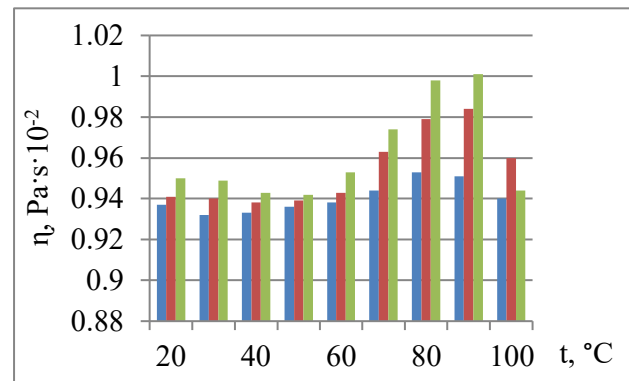

Egg mass content: $\quad \square 10 \% \square 15 \% \square 20 \%$

$b$

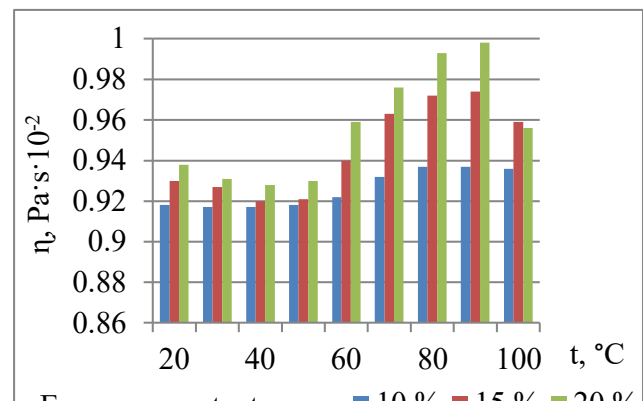

Egg mass content: $\quad-10 \% \square 15 \%=20 \%$

c

Fig. 3. Viscosity change at heating the model compositions with different egg mass concentration at $\mathrm{pH} 4.3$ and $\mathrm{NaCl}$ content: $a-0.5 \% ; b-1.0 \% ; c-1.5 \%$

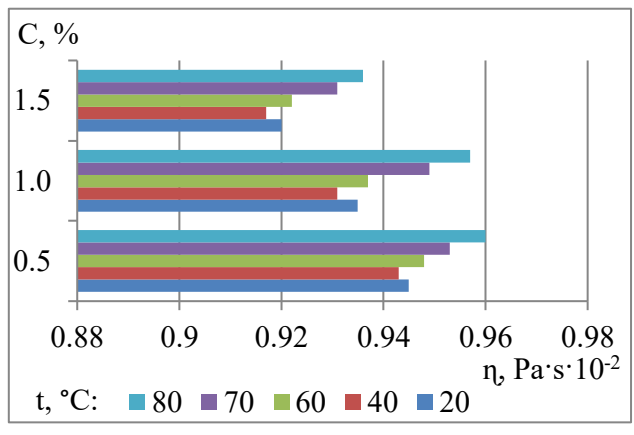

a

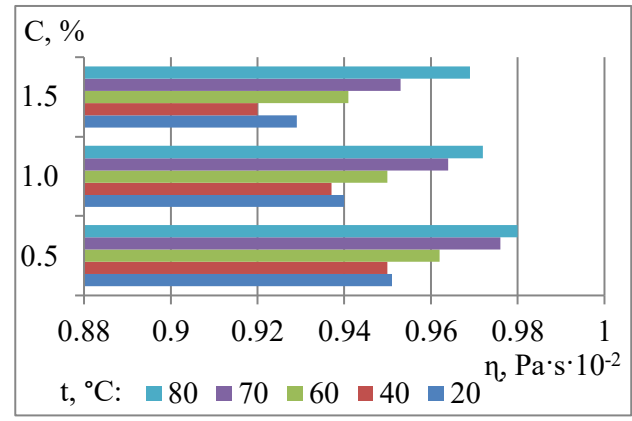

b

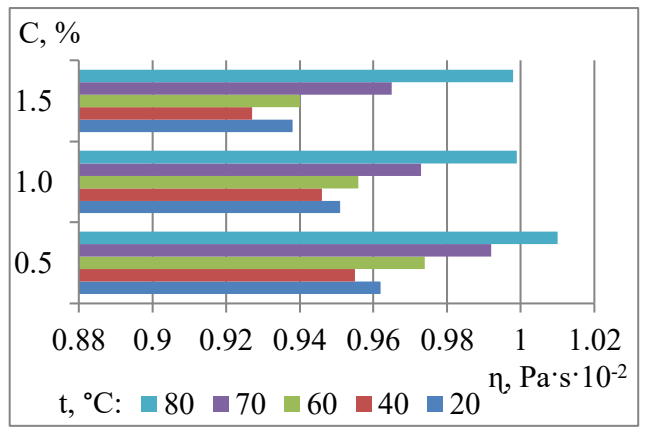

Fig. 4. Isothermal viscosity change depending on sodium chloride concentration in mixtures at $\mathrm{pH} 4.3$ and egg mass content: $a-10 \% ; b-15 \% ; c-20 \%$

6. Results of studying the comprehensive influence of the medium $\mathrm{pH}$ and sucrose concentration on the process of the thermal acid coagulation of egg proteins in a milk environment

We studied the comprehensive influence of active acidity and different concentrations of sucrose on the process of the coagulation of egg proteins in a similar way: the model systems were heated, and then the coagulation temperatures were recorded according to the viscosity of the system. The results of studies of the effect of different concentrations of sucrose on the coagulation of colloidal solutions of egg mass are shown in Fig. 5.

The curves are approximated and expressed by functions (y) indicating the degree of the approximation reliability $\left(R^{2}\right)$ :

$y(1)=4 \mathrm{E}-09 x^{4} y 1 \mathrm{E}-06 x^{3}+0,0001 x^{2} y 0,0049 x+1,0109$, $R^{2}=0,9927$

$y(2)=1 \mathrm{E}-09 x^{4} y 7 \mathrm{E}-07 x^{3}+1 \mathrm{E}-04 x^{2} y 0,0041 x+0,9959$, $R^{2}=0,9885$ 
$y(3)=1 \mathrm{E}-10 x^{4} y 5 \mathrm{E}-07 x^{3}+9 \mathrm{E}-05 x^{2} y 0,0041 x+0,9893$, $R^{2}=0,9817$

$y(4)=-8 \mathrm{E}-10 x^{4} y 4 \mathrm{E}-07 x^{3}+9 \mathrm{E}-05 x^{2} y 0,0042 x+0,987$, $R^{2}=0,9749$;

$y(5)=-6 \mathrm{E}-10 x^{4} y 7 \mathrm{E}-07 x^{3}+0,0001 x^{2} y 0,0053 x+0,9962$, $R^{2}=0,9447$

$y(6)=9 \mathrm{E}-09 x^{4} y 3 \mathrm{E}-06 x^{3}+0,0003 x^{2} y 0,0097 x+1,0526$, $R^{2}=0,8858$

The next series of experiments determined the comprehensive stabilizing effect exerted on the coagulation of egg proteins by sucrose and the active acidity of an environment. The change in the viscosity of the experimental three-component systems when heated is shown in Fig. 6.

The isothermal viscosity change depending on sugar concentration at different egg mass content in the system is shown in Fig. 7.

The results of studying the comprehensive influence of the medium $\mathrm{pH}$ and sucrose concentration on the process of the coagulation of egg mass are shown in Fig. 8, 9.

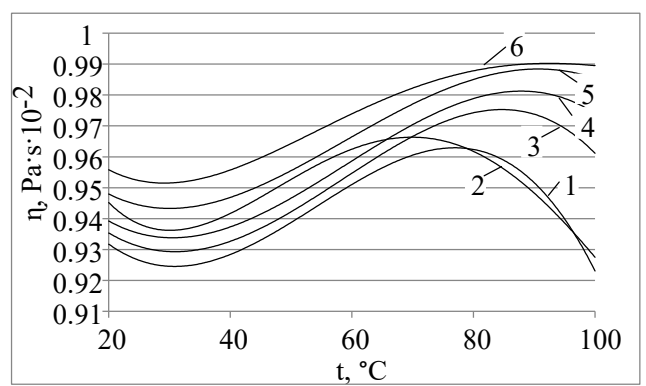

Fig. 5. Viscosity change at heating the colloid solution of egg mass of $15 \%$ concentration at sugar content: $1-0 \% ; 2-5 \% ; 3-10 \% ; 4-15 \%$; $5-20 \%, 6-25 \%$

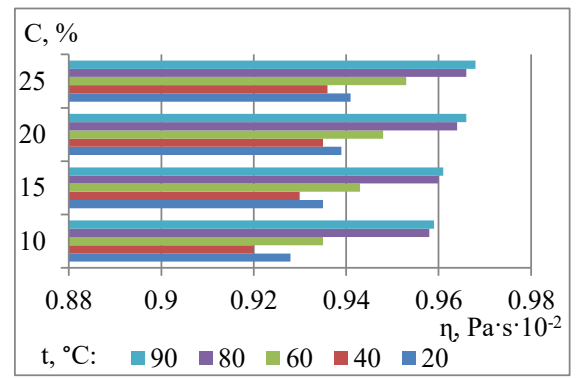

$a$
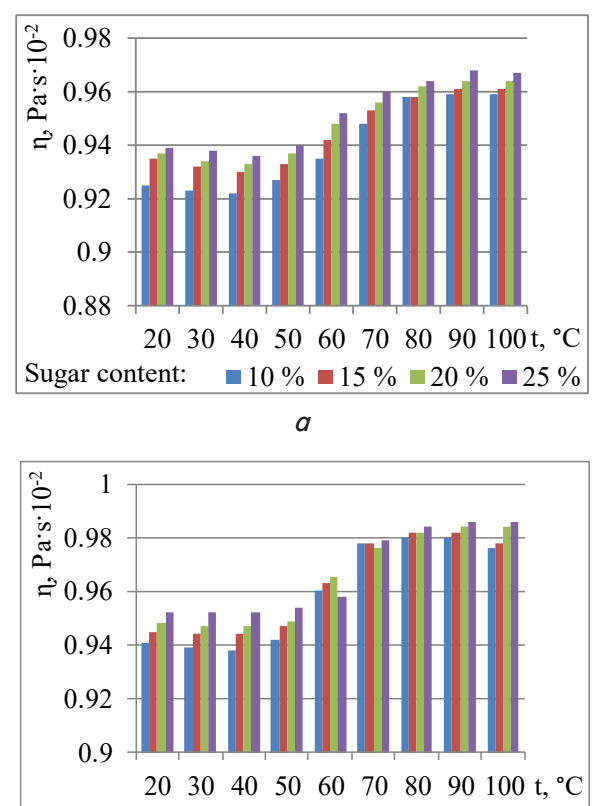

Sugar content: $\quad \square 10 \% \square 15 \%-20 \% \square 25 \%$

$b$

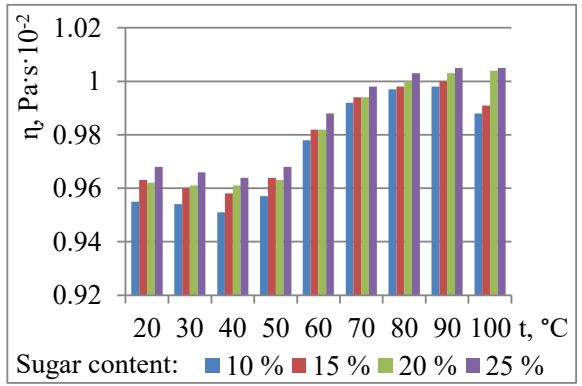

Fig. 6 . Viscosity change at heating the mixture with different sugar content in the system at egg mass concentration: $a-10 \% ; b-15 \% ; c-20 \%$

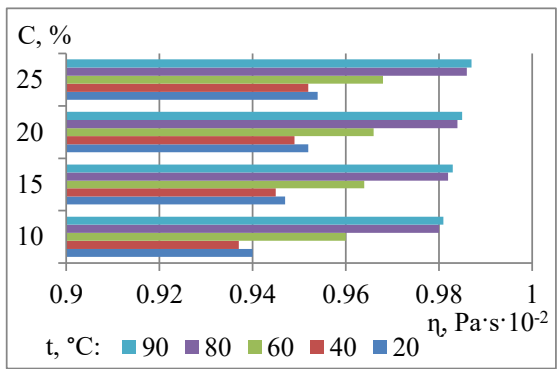

$b$

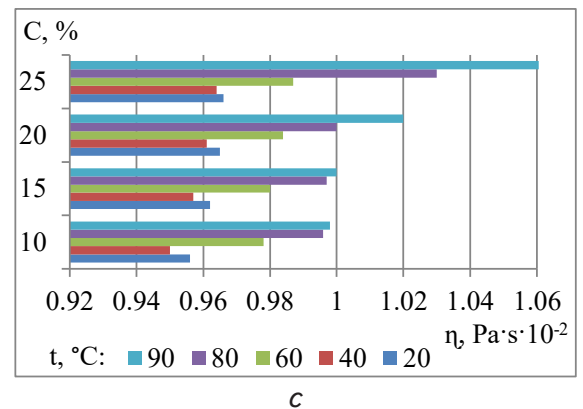

Fig. 7. Isothermal viscosity change depending on sugar concentration in the mixture at $\mathrm{pH} 4.8$ and egg mass content: $a-10 \% ; b-15 \% ; c-20 \%$ 


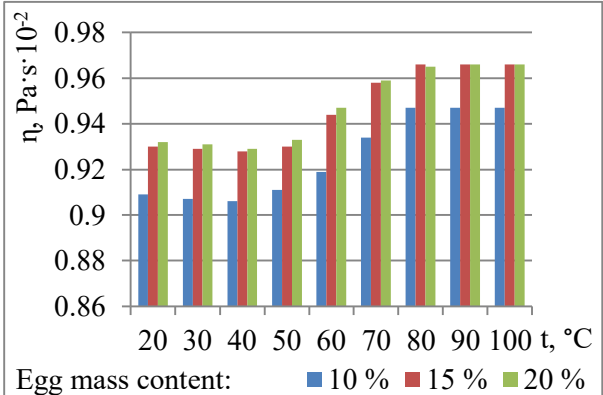

$a$

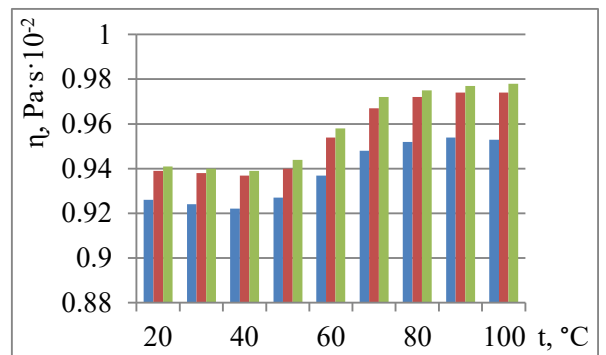

Egg mass content:

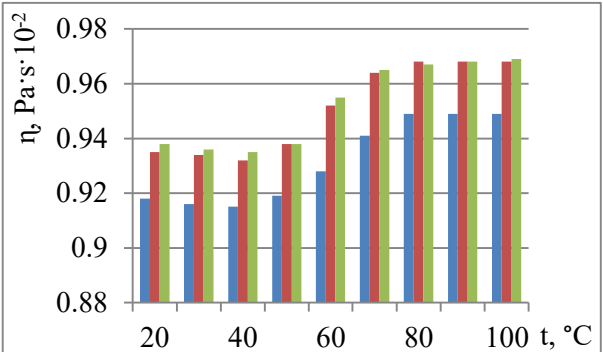

Egg mass content: $\quad-10 \%-15 \%-20 \%$

b

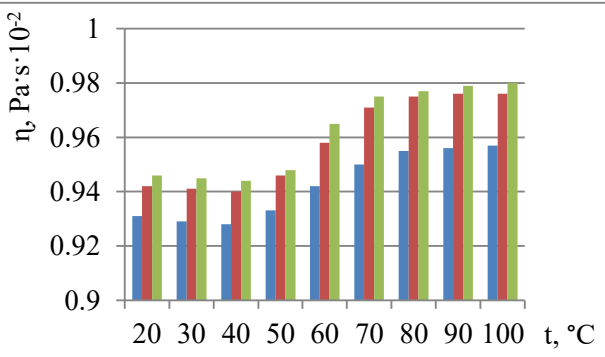

Egg mass content: $-10 \%-15 \%-20 \%$

Fig. 8. Viscosity change at heating the model compositions with a different egg mass concentration at pH 4.5 and sugar content: $a-10 \% ; b-15 \% ; c-20 \% ; d-25 \%$
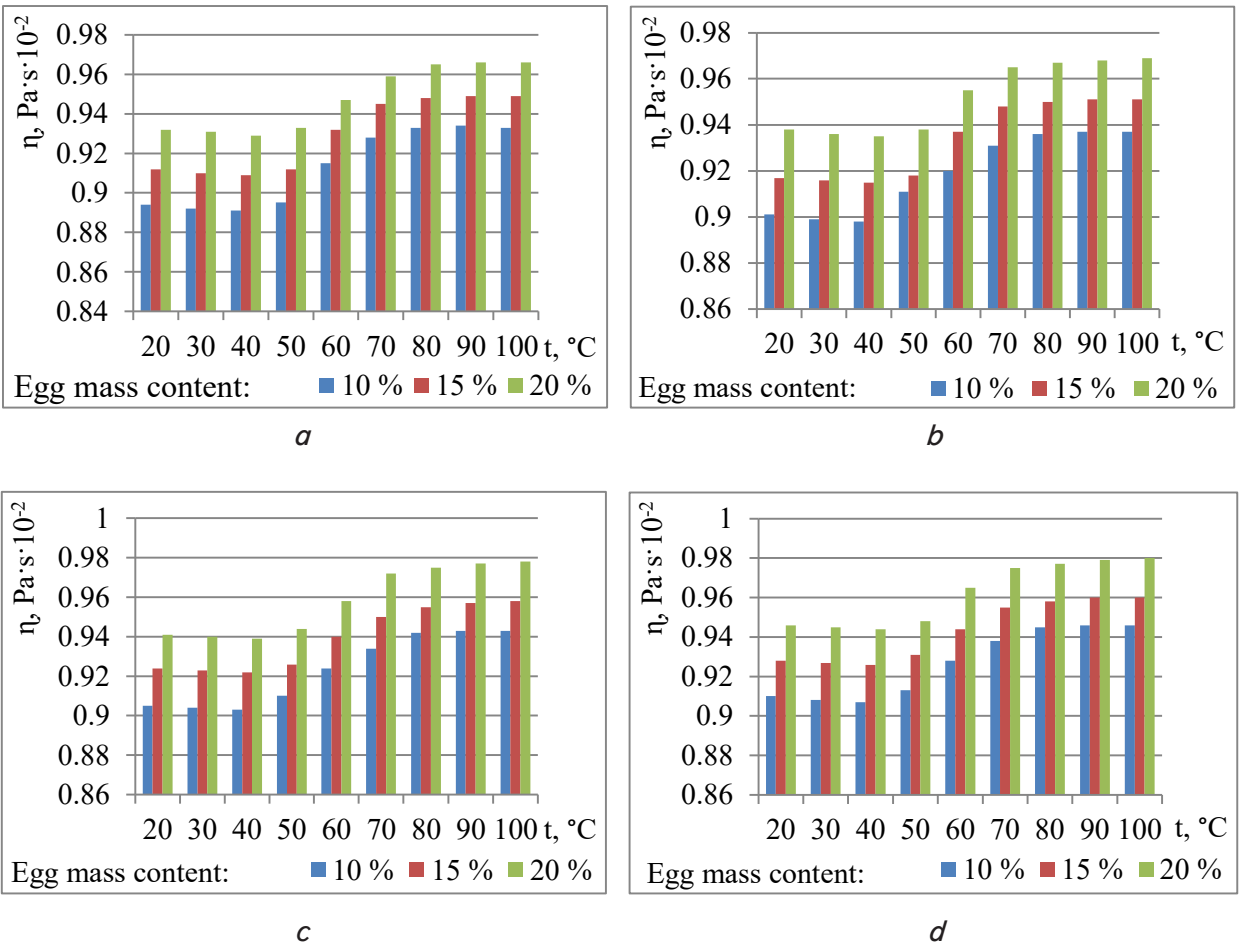

Fig. 9. Viscosity change at heating the model compositions with a different egg mass concentration at $\mathrm{pH} 4.2$ and sugar content: $a-10 \% ; b-15 \% ; c-20 \% ; d-25 \%$

\section{Discussion of results of studying the comprehensive influence of sodium chloride, sucrose, and $\mathrm{pH}$ on the process of the coagulation of egg proteins}

As one can see from the data shown in Fig. 1, sodium chloride in low concentrations reduces the viscosity of the colloidal solution of the egg mass and slightly increases the temperature of the thermal coagulation of egg proteins. At the same time, in the region of $20 \ldots 50{ }^{\circ} \mathrm{C}$, there is a slight decrease in viscosity, which is probably due to the melting of the fat contained in the system.

In the region of $50 \ldots 80{ }^{\circ} \mathrm{C}$, there is an intensive increase in viscosity, which is the result of the latent coagulation of egg proteins.

In the final region $\left(80 \ldots 100{ }^{\circ} \mathrm{C}\right)$, a sharp decrease in the viscosity of the system can be observed, which occurs due to its separation and deposition of the protein clot. The peaks of the curves (Fig. 1) show that it is at these specific temperatures that a protein clot forms and these temperatures should be considered as the temperatures of explicit (visible) protein coagulation.

Therefore, according to the data shown in Fig. 1, it can be argued that sodium chlori-de increases the heat resistance of egg proteins by $6 . . .8$ degrees, which corresponds to the literature data [15].

The results of the research shown in Fig. 2 demonstrate that the active acidity of curd whey significantly affects the coagulation temperature of egg proteins. Thus, when the active acidity is shifted to the acidic side ( $\mathrm{pH} 4.3$ ), the coagulation temperature of egg proteins is, depending on the concentration of egg mass, $80 \ldots 82^{\circ} \mathrm{C}$, which is $10 \ldots 12 \mathrm{de}-$ grees higher than the coagulation temperature of egg proteins in a neutral medium.

Shifting the $\mathrm{pH}$ towards neutral values reduces the coagulation temperature. Thus, a change in $\mathrm{pH}$ from 4.3 to 4.6 reduces the heat resistance of proteins and the formation of a protein clot by 5...8 degrees (Fig. 2). This is due to the fact that at $\mathrm{pH}$ values close to the isoelectric point of the protein, coagulation occurs at lower temperatures. The isoelectric point of egg proteins is in the range of $4.55 \ldots 5.60[4,15]$. Shifting the medium $\mathrm{pH}$ towards one or another side from the isoelectric point helps increase its thermal stability. Accordingly, it can 
be assumed that a further increase in the $\mathrm{pH}$ values in the system under consideration would further reduce the temperature of the explicit coagulation and clot formation. Since our research is aimed at determining the rational parameters for obtaining milk-egg protein concentrates, it is advisable for further research to maintain the active acidity of the experimental systems at the level not exceeding 4.3...4.5.

Regarding the combined use of sodium chloride and the $\mathrm{pH}$ medium, it leads, according to the analysis of the graphical dependences shown in Fig. 3, to a synergistic effect on the heat resistance of egg proteins. In this case, the value of the temperature of visible coagulation depends on the concentration of egg mass in the model systems. Thus, at $20 \%$ of the egg mass content, the maximum values of the temperature of visible coagulation of egg proteins are in the range of $88 \pm 0.5^{\circ} \mathrm{C}$ (at $\mathrm{pH} 4.2 \ldots 4.3$ ). Reducing the concentration of egg mass to $15 \%$ and below, to $10 \%$, allows one to bring the temperature of visible coagulation to $91 \pm 0.5^{\circ} \mathrm{C}$, which almost corresponds to the temperature of the latent coagulation of whey proteins.

The isothermal change in the viscosity of the system at different concentrations of sodium chloride (Fig. 4) indicates a change in the values of $\eta$ when increasing $C$, while the rate of the decrease in viscosity slows down significantly with increasing temperature and an increasing concentration of egg mass.

Thus, the most rational quantitative content of egg mass in the system, which allows achieving the optimal temperature of the coagulation of egg proteins and curd whey, is its $15 \%$ concentration at a content of $1.0 \ldots 1.5 \%$ of sodium chloride and a system $\mathrm{pH}$ of $4.2 \ldots 4.3$.

Fig. 5 shows the change in viscosity when heating a colloidal solution of the egg mass of $15 \%$ concentration depending on sugar content. As one can see from the graphical dependences shown in Fig. 5, with an increasing amount of sugar in the solution, the viscosity of the system initially decreases, which, as already mentioned, is a consequence of the process of fat melting. In this case, the introduction of sugar in the amount of $5 \ldots 15 \%$ initially reduces the viscosity of the system compared to the viscosity of the colloidal solution of the egg mass.

In the temperature interval of $40 \ldots 80^{\circ} \mathrm{C}$, there is a sharp increase in $\eta$, which occurs due to the latent coagulation of egg proteins. Sugar stabilizes the system by raising the coagulation temperature of egg proteins.

It should also be noted that when sugar is introduced into the system in the amount of $5 \%$, the stabilizing effect is insufficient, due to which the stratification of the mixture occurs at a temperature of $80{ }^{\circ} \mathrm{C}$. Increasing the concentration of sugar in the system to $10 . .15 \%$ has a greater stabilizing effect; the stratification temperature of the system rises to $87 \ldots 90{ }^{\circ} \mathrm{C}$. A larger increase in the sugar content further stabilizes the system and, even in the temperature interval of $90 \ldots 100{ }^{\circ} \mathrm{C}$, the values of $\eta$ remain constant or slightly reduce, that is, the system does not stratify.

Of particular interest is the sensory evaluation of the homogeneity of experimental model systems after heating them to $100{ }^{\circ} \mathrm{C}$. Thus, the introduction of sugar in the amount of $5 \%$ leads to a clearly stratified system consisting of the liquid phase of low viscosity and a precipitate in the form of large egg clots. Model systems containing 10...15\% of sugar represented a liquid phase of medium viscosity with the presence of flake-like inclusions of size $(2 \ldots 3) \cdot 10^{-3} \mathrm{~m}$. The systems with a sugar content of $20 \ldots 25 \%$ after pasteur- ization contained evenly distributed suspended flake-like particles the size of $(0.5 \ldots 1) \cdot 10^{-3} \mathrm{~m}$.

Thus, for subsequent research into determining the parameters of obtaining milk-egg protein concentrates, model systems with a sugar concentration of $10 . . .25 \%$ were selected.

The change in the viscosity of the experimental three-component systems when heated is shown in Fig. 6. As one can see from Fig. 6, the stabilizing effect of sucrose at $\mathrm{pH} 4.8$ is more pronounced compared to a neutral environment. The stratification of the systems and the separation of sediment occurs at higher temperatures, while the systems with a low concentration of egg mass $(10 \%)$ maintained integrity even at $100{ }^{\circ} \mathrm{C}$. With increasing sugar content, the resistance against stratification by the experimental dispersed systems increases; no separation of sediment was observed.

It should also be noted that the viscosity of the model systems is derived from the concentration of both sucrose and egg mass. Thus, with increasing sucrose content from 10 to $25 \%$, the values of $\eta$ increase from $0.928 \cdot 10^{-2} \mathrm{~Pa} \cdot \mathrm{s}$ to $0.940 \cdot 10^{-2} \mathrm{~Pa} \cdot \mathrm{c}$ (at $T=50^{\circ} \mathrm{C}$ ) and from $0.957 \cdot 10^{-2} \mathrm{~Pa} \cdot \mathrm{s}$ to $0.965 \cdot 10^{-2} \mathrm{~Pa} \cdot \mathrm{s}$ (at $T=80^{\circ} \mathrm{C}$ ). Increasing the concentration of egg mass significantly increases the $\eta$ value, from $0.928 \cdot 10^{-2} \mathrm{~Pa} \cdot \mathrm{s}$ at $10 \%$ egg mass to $0.958 \cdot 10^{-2} \mathrm{~Pa} \cdot \mathrm{s}$ at $20 \%$ of its content (for mixtures with $10 \%$ sugar and $T=50{ }^{\circ} \mathrm{C}$ ). This is also evidenced by the isothermal change in viscosity depending on the concentration of sugar at a different content of the egg mass in the system (Fig. 7).

With increasing active acidity of the experimental model systems, the stabilizing effect of the comprehensive influence of the medium $\mathrm{pH}$ and the concentration of sucrose on the process of the coagulation of egg mass intensified (Fig. 8, 9). Stratification of the system was not observed in any of the cases; with an increasing concentration of sucrose in the system and decreasing $\mathrm{pH}$ values, the viscosity of the systems increased.

Based on the research results, it was determined that the most rational content in the system, for obtaining milk-egg protein concentrates, is $15 \ldots 20 \%$ of egg mass and $20 \ldots 25 \%$ of sugar, which allows the pasteurization of the mixture at $85 \ldots 90{ }^{\circ} \mathrm{C}$ without stratification, and contributes to the system achieving maximum viscosity values.

Thus, our research makes it possible to resolve the task of determining the parameters for the coagulation of egg proteins in a milk environment, in particular, taking into consideration the type of food for the production of which the obtained concentrates would be used. Thus, for the production of traditional food products, it is advisable to perform the co-deposition of egg proteins and curd whey, under the following conditions: the content of egg mass in the food system is $15 \%$, sodium chloride content is $1.0 \ldots 1.5 \%$, a pH of the system is $4.2 \ldots 4.3$. For the production of sweet foods, it is advisable to perform the thermal acid coagulation of egg and milk proteins with content of $15 . .20 \%$ of egg mass in the food system, $20 \ldots 25 \%$ of sugar content, and $\mathrm{pH}$ of the system is $4.2 \ldots 4.5$.

The obtained results take into consideration the features of the compatible thermal acid coagulation of egg and milk proteins, which have not been previously studied. The application of coagulation parameters determined as a result of this study avoids significant deficiencies, in particular, the formation of a product with a heterogeneous structure in the manufacture of milk-egg concentrates. The 
obtained research results could be used in the production of milk and egg concentrates under industrial conditions and at restaurants, applying the formulation components and technological parameters specified in this work. To vary the $\mathrm{pH}$ values when working with food systems, it is appropriate to replace $\mathrm{HCl}$ and $\mathrm{NaOH}$ solutions with food acidity regulators.

The potential use of the studied food systems is limited by the starting formulation components. Further studies of food systems, the production of which would involve a change in formulation components, can be considered relevant. In particular, given the constant increase in the number of patients with diabetes, it is important to study the effect of sugar substitutes (xylitol, sorbitol, stevia extract, etc.) on the process of the thermal acid coagulation of egg proteins in a milk environment. Such studies could expand the range of protein products for diabetics.

\section{Conclusions}

1. The process of the thermal coagulation of proteins of the egg mass in a milk medium depending on the medium $\mathrm{pH}$ and the concentration of sodium chloride was studied; it was determined that the optimum temperature for the coagulation of egg proteins and curd whey can be achieved at a $15-\%$ concentration of egg mass in the system, $1.0 \ldots 1.5 \%$ of sodium chloride content, and the system $\mathrm{pH}$ of $4.2 \ldots 4.3$.

2. The comprehensive influence of the medium $\mathrm{pH}$ and sucrose concentration on the process of egg protein coagulation was studied; it was found that the most rational content, when obtaining milk-egg protein concentrates, is $15 . .20 \%$ of egg mass and $20 \ldots 25 \%$ of sugar in the system, which allows the pasteurization of the mixture at $85 \ldots 90{ }^{\circ} \mathrm{C}$ without stratification, as well as helps the system achieve maximum viscosity values.

\section{References}

1. Krasheninin, P. F., Ivanova, L. N., Meduzov, V. S. et. al. (1988). Tehnologiya detskih i dieticheskih molochnyh produktov. Moscow: Agropromizdat, 232.

2. Levashov, P. A., Matolygina, D. A., Dmitrieva, O. A., Ovchinnikova, E. D., Adamova, I. Y., Karelina, N. V. et. al. (2019). Covalently immobilized chemically modified lysozyme as a sorbent for bacterial endotoxins (lipopolysaccharides). Biotechnology Reports, 24, e00381. doi: https://doi.org/10.1016/j.btre.2019.e00381

3. Davies, D. T., Law, A. J. R. (1983). Variation in the protein composition of bovine casein micelles and serum casein in relation to micellar size and milk temperature. Journal of Dairy Research, 50 (1), 67-75. doi: https://doi.org/10.1017/s0022029900032532

4. Deinychenko, H. V., Yudina, T. I. (2008). Funktsionalno-tekhnolohichni vlastyvosti bahatokomponentnykh system na osnovi kontsentratu zi skolotyn. Zb. nauk. prats Luhanskoho natsionalnoho ahrarnoho universytetu. Seriya: tekhnichni nauky, 88, 138-140.

5. Hramtsov, A. G., Nesterenko, P. G. (2004). Tehnologiya produktov iz molochnoy syvorotki. Moscow: DeLiprint, 587.

6. Hegg, P.-O. (1979). Precipitation of egg white proteins below their isoelectric points by sodium dodecyl sulphate and temperature. Biochimica et Biophysica Acta (BBA) - Protein Structure, 579 (1), 73-87. doi: https://doi.org/10.1016/0005-2795(79)90088-6

7. Akkouche, Z., Aissat, L., Madani, K. (2012). Effect of Heat on Egg White Proteins. International Conference on Applied Life Sciences. IntechOpen, 407-413. Available at: https://www.researchgate.net/publication/233726908_Effect_of_Heat_on_Egg_ White_Proteins

8. Liu, Y.-F., Oey, I., Bremer, P., Carne, A., Silcock, P. (2017). Effects of pH, temperature and pulsed electric fields on the turbidity and protein aggregation of ovomucin-depleted egg white. Food Research International, 91, 161-170. doi: https://doi.org/10.1016/ j.foodres.2016.12.005

9. Liu, Y.-F., Oey, I., Bremer, P., Silcock, P., Carne, A. (2017). In vitro peptic digestion of ovomucin-depleted egg white affected by pH, temperature and pulsed electric fields. Food Chemistry, 231, 165-174. doi: https://doi.org/10.1016/j.foodchem.2017.03.136

10. Li, J., Zhang, M., Chang, C., Gu, L., Peng, N., Su, Y., Yang, Y. (2018). Molecular forces and gelling properties of heat-set whole chicken egg protein gel as affected by $\mathrm{NaCl}$ or pH. Food Chemistry, 261, 36-41. doi: https://doi.org/10.1016/j.foodchem.2018.03.079

11. Ferreira Machado, F., Coimbra, J. S. R., Garcia Rojas, E. E., Minim, L. A., Oliveira, F. C., Sousa, R. de C. S. (2007). Solubility and density of egg white proteins: Effect of pH and saline concentration. LWT - Food Science and Technology, 40 (7), $1304-1307$. doi: https://doi.org/10.1016/j.lwt.2006.08.020

12. Nasabi, M., Labbafi, M., Mousavi, M. E., Madadlou, A. (2017). Effect of salts and nonionic surfactants on thermal characteristics of egg white proteins. International Journal of Biological Macromolecules, 102, 970-976. doi: https://doi.org/10.1016/ j.ijbiomac.2017.04.102

13. Bogdanova, E. A., Hondak, R. N. et. al. (1989). Tehnologiya tsel'nomolochnyh produktov i molochno-belkovyh kontsentratov. Moscow: Agropromizdat, 273.

14. Vinogradov, G. V., Zabugina, M. P., Konstantinov, A. A., Konyukh, I. V., Malkin, A. Y., Prozorovskaya, N. V. (1964). Viscosity measurements of condensed polymers by rotary and capillary viscometers. Polymer Science U.S.S.R., 6 (9), 1823-1828. doi: https:// doi.org/10.1016/0032-3950(64)90277-1

15. Guslyanikov, V. V., Podlegaev, M. A. (1979). Tehnologiya myasa ptitsy i yaytseproduktov. Moscow: Pishchevaya promyshlennost', 288. 